\title{
Quality of life and its determinants: A study among cancer patients in radiotherapy outpatient department of a tertiary care hospital of Kolkata
}

\author{
Sinjita Dutta ${ }^{1}$, Abhishek De ${ }^{2, *}$, Sarbajit Ray ${ }^{3}$, Mausumi Basu ${ }^{4}$, Raghunath Misra ${ }^{5}$ \\ ${ }^{1,4}$ Assistant Professor, ${ }^{2}$ Demonstrator, ${ }^{1,2,4}$ Dept. of Community Medicine, Institute of Post-Graduate Medical Education and \\ Research, Kolkata, ${ }^{3}$ RMO-cum-Clinical Tutor, Dept. of Medicine, Medical College, Kolkata, ${ }^{5}$ Professor and HOD, ${ }^{4}$ Dept. of \\ Community Medicine, Institute of Post-Graduate Medical Education and Research, Kolkata, India
}

*Corresponding Author:

Email: dr.abhishek.de@gmail.com

\begin{abstract}
Introduction: Cancer patients suffer a lot physically, emotionally \& practically. In some cancer disease quality of life has become an important end point for treatment. Thus quality of life assessment becomes an important issue among cancer patients. Objective: To evaluate the quality of life of cancer patients attending Radiotherapy OPD in IPGMER, Kolkata and to find out, if any association of socio-demographic profile with the quality of life.

Materials and Methods: A descriptive type of observational study, with cross sectional study design was conducted among the patients attending Radiotherapy OPD of I.P.G.M.E.R. \& S.S.K.M Hospital.

Results: The most negatively affected domain by cancer was the psychological domain which had the lowest mean score among all the domains (37.25 \pm 16.3 ). Mean scores in psychological (41.4) and environmental domain (54.3) were significantly ( $p<0.05)$ higher in persons suffering from cancer for more than 5 years. Mean scores were also higher in all the domains in patients who had undergone some form of surgical interventions for their cancer.

Conclusions: Most affected by cancer is psychological quality of life. But with longer duration of cancer patients seemed to get adjusted with the suffering. Undergoing surgery not only improved physical perception of health, but also acted as a psychological boost up.
\end{abstract}

Keywords: Quality of life, Domains, Duration of cancer, Cancer related surgery.

\section{Introduction}

Cancer is a disease of uncontrolled cellular proliferation. It is malignant and primary \& characterized by local cell invasion \& metastasis. Cancer can affect different systems or organs of the human body. The five most frequent cancers (ranking defined by total number of cases) in India in men and women are breast, cervical, oral cavity, lung and colorectal. ${ }^{1}$ In children acute lymphoblastic leukemia, brain tumors are common. Possible signs and symptoms include a new lump, changes in mole on the skin, indigestion, abnormal bleeding, cachexia, prolonged cough or change in bowel movements

In India it is estimated that around 2.5 million people are living with the disease. Every year, over 7 lakh new cancer patients are registered. There are 5, 56,400 cancer-related deaths annually in the country. ${ }^{2}$ Deaths occur mostly in the economically productive age group that is $30-69$ years. $71 \%$ of all cancer related deaths occur in the age group between 30-69 years which totals to 3,95,400 deaths annually (Men: 2,00,100 and Women: 1,95,300). ${ }^{3}$

Cancers of oral cavity and lungs in males and cervix and breast in females account for over $50 \%$ of all cancer deaths in India. ${ }^{4}$

Though considered as a terminal disease by many people, chances of survival depend on the type of cancer and the extent of the disease at the start of treatment. In children less than 15 years at diagnosis, the 5 year survival rate in the developed world is on average $80 \%{ }^{5}$

The cancer patients suffer a lot physically, emotionally \& financially. After diagnosis with cancer, patients feel full range of emotions including fear, sadness, anxiety and depression. Patients often suffer from cognitive problems like thinking, memory, concentration $\&$ behavior. It becomes very upsetting for the patients to realize that they are suffering cancer and come to terms with the diagnosis.

Again treatment like chemotherapy, radiation, targeted therapies cause pain \& discomfort. Having cancer also means earning less, working less. Cancer affects the personal finances of the patients - who spend most of their savings in treatment.

Thus cancer not only affects the person with the illness but also their family members \& friends. The friends \& family members also face cancer alongside a loved one. Lack of social care, improper adjustment reduces quality of life which should be studied well to support better treatment \& psychotherapy should be encouraged.

Thus an increasingly important issue in oncology is to evaluate Quality of life (QoL) in cancer patients. ${ }^{6}$ Quality of life is an individuals' perception of their aims, expectations, interests and ideas, satisfaction and happiness among their culture and values as a whole. ${ }^{7}$

World Health Organization (WHO) defines Quality of life (QoL) as "the individual's perception of their position in life in the context of the culture and value 
systems in which they live and in relation to their goals." QoL is increasingly being used as a primary outcome measure in studies to evaluate the effectiveness of treatment. ${ }^{8-11}$

Studies have been more on the death due to cancer than those surviving after cancer, so life quality among them often remain unaddressed.

Thus this study was carried out to evaluate the quality of life of cancer patients attending radiotherapy OPD in IPGME\&R and to elicit if any the relationship between the quality of life and socio-demographic profile of the patients.

\section{Materials and Methods}

A descriptive type of observational study, with cross sectional study design was conducted among the patients attending Radiotherapy OPD of I.P.G.M.E.R. \& S.S.K.M Hospital, Kolkata, in March 2017 spanning a period of one month.

Non random purposive sampling technique was followed. The OPD was visited for 4 hours (from 9am to 12 noon) for 2 weeks. All the patients attending the OPD during the visit were interviewed after taking informed oral consent after their visit at the OPD. Any medical report available with them was also examined for additional information.

Exclusion criteria included patients who were below 18 years of age and who were seriously ill. Thus a total sample size 275 was obtained.

The study tools included predesigned and pretested structured schedule and the WHO Quality of Life BREF (WHOQOL-Bref) Questionnaire (Bengali Version)

The WHOQOL-100 quality of life assessment was developed by the WHOQOL Group with fifteen international field centers, simultaneously, in an attempt to develop a quality of life assessment that would be applicable cross-culturally. To provide a broad and comprehensive assessment, one item from each of the 24 facets contained in the WHOQOL-100 has been included QOL Bref Scale. In addition, two items from the Overall quality of Life and General Health facet have been included. The WHOQOL-BREF thus contains a total of 26 questions. The WHOQOL-BREF is therefore based on a four domain structure as mentioned below

\begin{tabular}{|c|c|}
\hline Doma i n & Facets incorporated within domains \\
\hline 1. Physical health & $\begin{array}{l}\text { Activities of daily living } \\
\text { Dependence on medicinal substances and medical aids } \\
\text { Energy and fatigue } \\
\text { Mobility } \\
\text { Pain and discomfort } \\
\text { Sleep and rest } \\
\text { Work Capacity }\end{array}$ \\
\hline 2. Psychological & $\begin{array}{l}\text { Bodily image and appearance } \\
\text { Negative feelings } \\
\text { Positive feelings } \\
\text { Self-esteem } \\
\text { Spirituality / Religion / Personal beliefs } \\
\text { Thinking, learning, memory and concentration }\end{array}$ \\
\hline 3. Social relationships & $\begin{array}{l}\text { Personal relationships } \\
\text { Social support } \\
\text { Sexual activity }\end{array}$ \\
\hline 4. Environment & $\begin{array}{l}\text { Financial resources } \\
\text { Freedom, physical safety and security } \\
\text { Health and social care: accessibility and quality } \\
\text { Home environment } \\
\text { Opportunities for acquiring new information and skills } \\
\text { Participation in and opportunities for recreation / leisure activities } \\
\text { Physical environment (pollution / noise / traffic / climate) } \\
\text { Transport }\end{array}$ \\
\hline
\end{tabular}




\section{Results and Analysis}

Fig. 1 shows the distribution of the study population according to their age groups. It was seen from table no. 1 that nearly $30 \%$ of the study population were between $41-50$ years of age.

Table 1 shows the distribution of the study population according to other socio-demographic variables. A little more than half $(52.7 \%)$ of the study population were females and almost half were homemakers $(49.8 \%)$. Majority of the study population were Hindus $(71.3 \%)$, were currently married $(90.2 \%)$ and belonged to nuclear families (61. 5\%). Constituents of urban area were statutory towns, census towns and outgrowths + urban agglomeration. All places with a municipality, corporation, cantonment board or notified town area committee were considered as urban areas. All areas under Panchayat were considered as rural areas. About $2 / 3^{\text {rd }}$ of study population lived in rural area.

Only $13 \%$ of the study population had completed education higher secondary and above. According to the modified BG Prasad Scale (2016), about $40 \%$ of the study population belonged to class 5 socio-economic status.

Breast cancer was the most common type of cancer (29.5\%) accounting for about half of the cancers among female population, followed by lung cancer $(11.6 \%)$ as evident from Fig. 2.

Nearly $1 / 3^{\text {rd }}$ of the study population had scored below the $1^{\text {st }}$ quartile in the physical and social relationship domain of WHO-Bref QOL scale (Table 2). In the psychological and environmental domain only $24 \%$ and $18.5 \%$ could score above the $3^{\text {rd }}$ quartile respectively.

The mean score in the social relationship domain was the highest $(52.26 \pm 17.7)$ and the lowest was in the psychological domain $(37.25 \pm 16.3)$. So the most negatively affected domain by cancer was the psychological domain (Table 3)

Mean scores in psychological (41.4) and environmental domain (54.3) were higher in persons suffering from cancer for more than 5 years. This association was significant $(p<0.05)$ in case of environmental domain (Table 4), suggesting the adjustment of patients to their physical environment with time.

Again mean scores were higher in all the domains in patients who had undergone some form of surgical interventions for their cancer. This was statistically significant $(\mathrm{p}<0.05)$ in physical and psychological domain.

Table 5 shows the relationship of the sociodemographic variable with score obtained in the different domains of quality of life. On regression it was found that duration of cancer was significantly $(p<0.05)$ associated with psychological and environmental domain score whereas PCMI was significantly $(\mathrm{p}<0.05)$ associated with social relationship and environmental domain scores.

Histogram showing age distribution of the study population $(\mathrm{N}=\mathbf{2 7 5})$

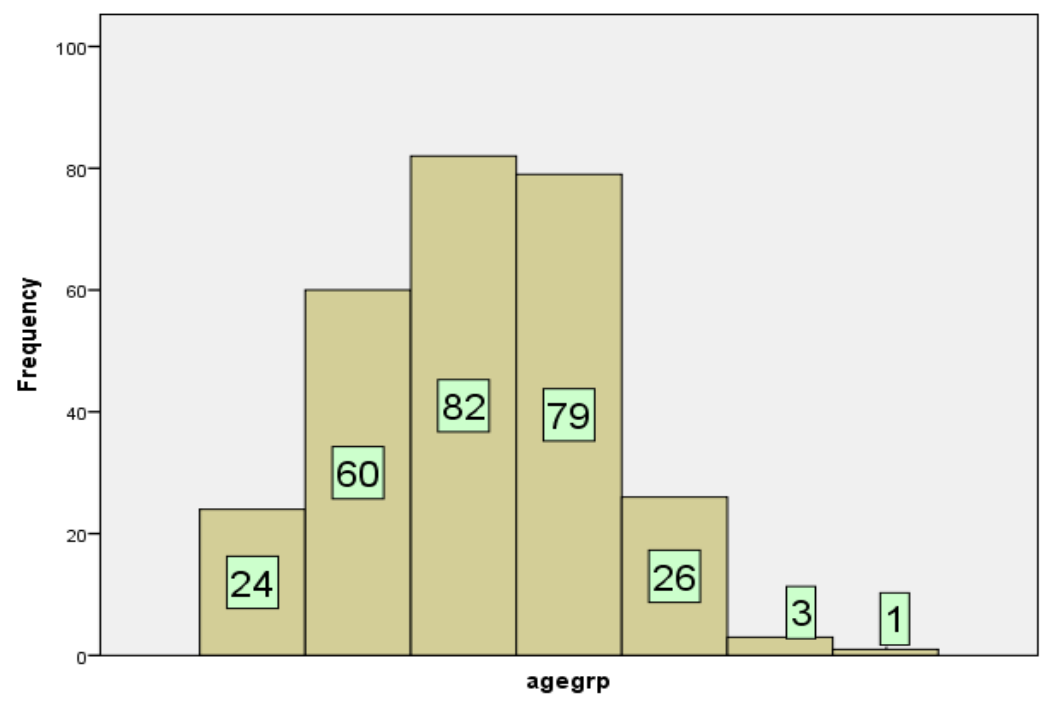

Fig. 1: 


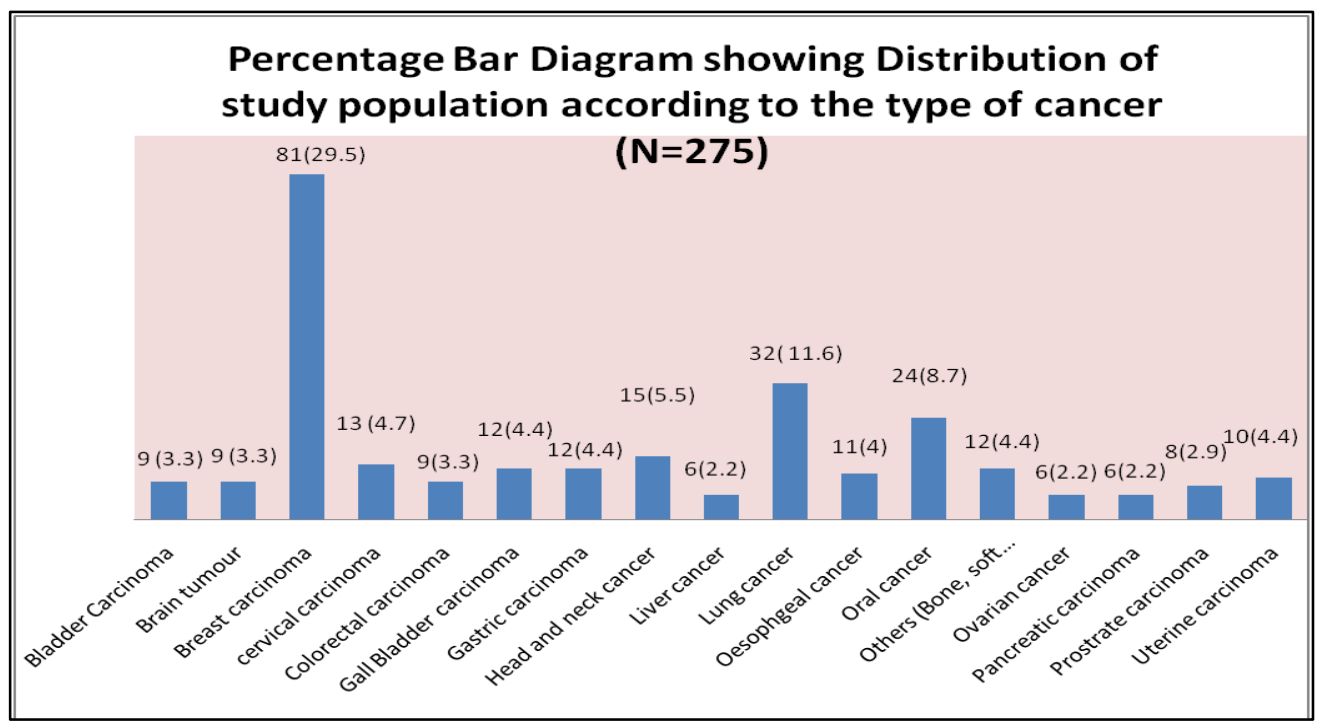

Fig. 2:

Table 1: Distribution of the study population according to their socio-demographic status $(\mathrm{N}=275)$

\begin{tabular}{|c|c|c|}
\hline Sex & Number & Percentage \\
\hline Female & 145 & 52.7 \\
\hline Male & 130 & 47.3 \\
\hline Religion & Number & Percentage \\
\hline Hindu & 196 & 71.3 \\
\hline Muslim & 76 & 26.9 \\
\hline Sikh & 3 & 1.1 \\
\hline Residence & Number & Percentage \\
\hline Rural & 183 & 66.5 \\
\hline Urban & 92 & 33.5 \\
\hline Marital status & Number & Percentage \\
\hline Married & 248 & 90.2 \\
\hline Unmarried & 11 & 4.0 \\
\hline Others(widow/widower, divorced, separated) & 16 & 5.8 \\
\hline Family type & Number & Percentage \\
\hline Joint & 106 & 38.5 \\
\hline Nuclear & 169 & 61.5 \\
\hline Occupation & Number & Percentage \\
\hline Businessman & 26 & 9.5 \\
\hline Service & 12 & 4.4 \\
\hline Farmer & 49 & 17.8 \\
\hline Home maker & 137 & 49.8 \\
\hline School teacher & 11 & 4 \\
\hline $\begin{array}{l}\text { Others (mason craftsman, priest, army, retired, driver, } \\
\text { carpenter, laborer, rickshaw puller, student, tailor) }\end{array}$ & 38 & 13.8 \\
\hline Unemployed & 2 & 0.7 \\
\hline Socio-economic Class & Number & Percentage \\
\hline Class 1 & 11 & 4.0 \\
\hline Class 2 & 20 & 7.3 \\
\hline Class 3 & 40 & 14.5 \\
\hline Class 4 & 92 & 33.5 \\
\hline Class 5 & 112 & 40.7 \\
\hline Education & Number & Percentage \\
\hline Illiterate & 84 & 30.5 \\
\hline Primary & 89 & 32.4 \\
\hline Middle School & 47 & 17.1 \\
\hline Secondary & 20 & 7.3 \\
\hline Higher Secondary & 12 & 4.4 \\
\hline Graduation and above & 23 & 8.4 \\
\hline
\end{tabular}


Table 2: Distribution of the study population according to the scores obtained in different domains ( $N=275)$

\begin{tabular}{|l|c|c|c|c|c|c|c|c|}
\hline \multirow{2}{*}{$\begin{array}{c}\text { Score } \\
\text { obtained }\end{array}$} & \multicolumn{2}{|c|}{ Physical health Domain } & \multicolumn{2}{c|}{ Psychological Domain } & \multicolumn{2}{c|}{$\begin{array}{c}\text { Social relationship } \\
\text { Domain }\end{array}$} & \multicolumn{2}{l|}{ Environment Domain } \\
\cline { 2 - 10 } & Number & Percentage & Number & Percentage & Number & Percentage & Number & Percentage \\
\hline Poor & 93 & 33.8 & 76 & 27.6 & 90 & 32.7 & 77 & 28.0 \\
\hline Average & 47 & 17.1 & 83 & 30.2 & 62 & 22.5 & 92 & 33.5 \\
\hline Good & 68 & 24.7 & 50 & 18.2 & 78 & 28.4 & 55 & 20.0 \\
\hline Very good & 67 & 24.4 & 66 & 24.0 & 45 & 16.4 & 51 & 18.5 \\
\hline
\end{tabular}

Table 3: Comparison of the scores obtained by the study population in the four domains and overall perception of quality of life and health $(\mathrm{N}=\mathbf{2 7 5})$

\begin{tabular}{|l|c|c|c|c|}
\hline Domain & Mean Score & Std. Deviation & Minimum & Maximum \\
\hline Physical & 41.03 & 16.62 & 6 & 88 \\
\hline Psychological & 37.25 & 16.3 & 0 & 81 \\
\hline Social & 52.26 & 17.7 & 6 & 100 \\
\hline Environmental & 48.34 & 13.32 & 6 & 88 \\
\hline Overall quality of life & 2.44 & 0.81 & 1 & 4 \\
\hline Overall health & 2.36 & 0.89 & 1 & 5 \\
\hline
\end{tabular}

Table 4: Comparison of the scores obtained with duration of cancer and cancer related surgery ( $N=275)$

\begin{tabular}{|c|c|c|c|c|c|c|}
\hline & $\begin{array}{c}\text { Physical } \\
\text { domain Score } \\
( \pm \text { SD })\end{array}$ & $\begin{array}{l}\text { Psychological } \\
\text { domain Score } \\
\quad( \pm \text { SD })\end{array}$ & $\begin{array}{c}\text { Social } \\
\text { relationship } \\
\text { domain Score } \\
( \pm \mathrm{SD})\end{array}$ & $\begin{array}{l}\text { Environmental } \\
\text { domain Score } \\
( \pm \text { SD })\end{array}$ & $\begin{array}{c}\text { Overall } \\
\text { perception of } \\
\text { quality of life } \\
\text { Score }( \pm \text { SD }) \\
\end{array}$ & $\begin{array}{c}\text { Overall } \\
\text { perception o } \\
\text { health Score } \\
( \pm \text { SD })\end{array}$ \\
\hline $\begin{array}{l}\text { Duration of cancer } \\
<5 \text { years }(n=262)\end{array}$ & $41.3( \pm 16.5)$ & $37.0( \pm 16.3)$ & $52.3( \pm 17.9)$ & $48.0( \pm 13.5)$ & $2.4( \pm 0.8)$ & $2.4( \pm 0.9)$ \\
\hline $\begin{array}{l}\text { Duration of cancer } \\
\geq 5 \text { years }(n=13)\end{array}$ & $36.5( \pm 18.1)$ & $41.4( \pm 17.5)$ & $52.3( \pm 12.4)$ & $54.3( \pm 8.5)$ & $2.5( \pm 0.9)$ & $2.5( \pm 1.1)$ \\
\hline \multicolumn{2}{|r|}{$\begin{array}{l}\mathrm{t}=0.92 \\
\mathrm{p}=0.36\end{array}$} & $\begin{array}{l}\mathrm{t}=0.86 \\
\mathrm{p}=0.40\end{array}$ & $\begin{array}{l}\mathrm{t}=0.01 \\
\mathrm{p}=0.99\end{array}$ & $\begin{array}{c}\mathrm{t}=2.5 \\
\mathrm{p}=0.03\end{array}$ & $\begin{array}{l}\mathrm{t}=0.09 \\
\mathrm{p}=0.93\end{array}$ & $\begin{array}{l}\mathrm{t}=0.62 \\
\mathrm{p}=0.55\end{array}$ \\
\hline $\begin{array}{l}\text { Did not undergo } \\
\text { cancer related } \\
\text { surgery }(\mathrm{n}=147)\end{array}$ & $38.9( \pm 16.3)$ & $35.2( \pm 15.1)$ & $51.9( \pm 17.5)$ & $47.5( \pm 13.1)$ & $2.4( \pm 0.8)$ & $2.3( \pm 0.9)$ \\
\hline $\begin{array}{l}\text { Had cancer related } \\
\text { surgery } \\
(\mathrm{n}=128)\end{array}$ & $43.5( \pm 16.7)$ & $39.6( \pm 17.3)$ & $52.7( \pm 18.0)$ & $49.3( \pm 13.6)$ & $2.5( \pm 0.8)$ & $2.5( \pm 0.9)$ \\
\hline & $\begin{aligned} \mathrm{t}=2.3 \\
\mathrm{p}=0.02\end{aligned}$ & $\begin{array}{c}\mathrm{t}=2.2 \\
\mathrm{p}-0.03\end{array}$ & $\begin{array}{l}t=0.41 \\
p=0.68\end{array}$ & $\begin{array}{c}\mathrm{t}=1.2 \\
\mathrm{p}=0.25\end{array}$ & $\begin{array}{c}\mathrm{t}=1.6 \\
\mathrm{p}=0.11\end{array}$ & $\begin{array}{c}\mathrm{t}=1.7 \\
\mathrm{p}=0.09\end{array}$ \\
\hline
\end{tabular}

Table 5: Relationship of quality of life with different socio-demographic variables ( $N=\mathbf{2 7 5}$ )

\begin{tabular}{|l|c|c|c|c|c|c|c|c|c|c|c|c|}
\hline $\begin{array}{c}\text { Independent } \\
\text { variables }\end{array}$ & \multicolumn{3}{|c|}{ Physical domain } & \multicolumn{3}{c|}{$\begin{array}{c}\text { Psychological } \\
\text { domain }\end{array}$} & \multicolumn{2}{c|}{$\begin{array}{c}\text { Social relationship } \\
\text { domain }\end{array}$} & \multicolumn{2}{|c|}{ Environmental domain } \\
\hline & beta & $\mathbf{t}$ & $\mathbf{p}$ & beta & $\mathbf{t}$ & $\mathbf{p}$ & $\mathbf{b e t a}$ & $\mathbf{t}$ & $\mathbf{p}$ & beta & $\mathbf{t}$ & $\mathbf{p}$ \\
\hline Age group & -.022 & -.350 & .727 & .018 & .287 & .775 & .031 & .506 & .614 & .076 & 1.286 & .200 \\
\hline PCMI & .054 & .805 & .422 & .057 & .855 & .393 & .210 & 3.198 & .002 & .265 & 4.096 & .000 \\
\hline Duration & .011 & .172 & .863 & .128 & 2.10 & .037 & .083 & 1.388 & .166 & .118 & 1.994 & .047 \\
\hline Education & -.008 & -.111 & .912 & .011 & .164 & .870 & -.044 & -.672 & .502 & -.087 & -1.343 & .181 \\
\hline Marital status & -.052 & -.843 & .400 & .035 & .575 & .566 & -.104 & -1.739 & .083 & .031 & .522 & .602 \\
\hline
\end{tabular}

\section{Discussions}

In our study over half of the study population was females $(52.7 \%)$ and breast cancer was the most common type of cancer $(29.5 \%)$, followed by lung cancer $(11.6 \%)$. This reflects the national characteristic of the disease as breast cancer accounts for $27 \%$ of the total cancers in India. However lung cancer comprises of $6.9 \%$ of all cancers in both sexes but $11.3 \%$ of cancers among men nationally. ${ }^{12}$
In contrast to a study by Bayumi ${ }^{13}$ which found only $4 \%$ and $1 \%$ of the study population having nonfavorable score in physical activities and social status our study showed nearly $1 / 3^{\text {rd }}$ of the study population had scored below the $1^{\text {st }}$ quartile in the physical and social relationship domain of WHO-Bref QOL scale (Table 2).

The study found that the most negatively affected domain by cancer was the psychological domain 
However a study conducted by Mansano-Schlosser et $\mathrm{al}^{14}$ found that the Social and Physical domains were the most affected and the best preserved was the Environment domain.

In our study the mean scores were higher in all the domains in patients who had undergone some form of surgical interventions for their cancer. This was statistically significant $(\mathrm{p}<0.05)$ in physical and psychological domain. Thus undergoing surgery not only improved physical perception of health, but also acted as a psychological boost up.

In a similar study ${ }^{15}$ among patients affected by colorectal cancer, the most affected domain was the Environment, and the least affected was the Psychological, in patients without stomas. The same study found that in colostomy patients, the most affected was the Physical domain, and the least affected, the Social.

A study by Isikhan et al ${ }^{16}$ found that loss of organ had no effect on patient's quality of life. On the other hand, Arslan and Bölükbaş1 ${ }^{17}$ reported that operated patients had better life qualities.

In our study mean scores in psychological (41.4) and environmental domain (54.3) were higher in persons suffering from cancer for more than 5 years. This association was significant $(p<0.05)$ in case of environmental domain (Table 4). This might be possibly due to the adjustment of patients to their physical environment with time.

However Işıkhan et $\mathrm{al}^{16}$ did not find any relationship between disease period and quality of life.

Our study found on regression PCMI was significantly $\quad(\mathrm{p}<0.05)$ associated with social relationship and environmental domain scores. But age, education and marital status did not affect any of the 4 domains of quality of life

A study by Bayumi et $\mathrm{al}^{13}$ showed that there was no correlation between quality of life and age, gender, social status, marriage, and job. Similarly a study by Schlosser et $\mathrm{al}^{14}$ found that the overall Quality of Life scores did not differ according to socio-demographic characteristics. In various other studies by Lee et al, ${ }^{18}$ Huguet et $\mathrm{al}^{19}$ and Rabin et $\mathrm{al}^{20}$ on quality of life among cancer patients, just like in the present study, no association was found between quality of life and age or education.

Again a study by Ustundag et $\mathrm{al}^{21}$ also found Education did not affect the quality of life of the patients. This finding was corroborated by Lis et al ${ }^{22}$ and Yildiz et al. ${ }^{23}$

In contrast Knight et $\mathrm{al}^{24}$ found that lower education levels in urinary cancer patients had worse physical, social and role functions and experienced more side-effects. Can et $\mathrm{al}^{25}$ observed that university graduates had higher life levels than others. Güner et $\mathrm{al}^{26}$ similarly reported that the quality of life worsened when the education level was low.
Since the perception of quality of life is a highly subjective phenomenon some studies also indicate that factors such as age, female gender, low education level and not having a partner may be related to low quality of life. $^{27}$

In our study marital status was not significantly associated with quality of life in any of the domains. But a study conducted by Üstündag et al ${ }^{21}$ found that single patients had worse psychological and general well-being than married ones whereas marital status did not affect physical and social wellbeing. Some studies had indicated that married patients had higher quality of life and more family/friends. ${ }^{28,17}$ However similar to our study Armstrong et $\mathrm{al}^{29}$ and Lis et $\mathrm{al}^{22}$ indicated, that marital status did not influence quality of life.

\section{Conclusion and Recommendation}

From this cross-sectional study following essential points were concluded. Firstly the most negatively affected domain by cancer was psychological domain. Secondly longer the duration of cancer, higher were the mean scores in psychological environmental domain suggesting the adjustment of patients to their disease with time. Lastly apart from per capita monthly income none of the other socio-demographic variables affected the scores obtained in the 4 domains.

Quality of life is perceived differently by each person and it is therefore fundamental to treat each patient individually at both physical and psychological level to improve their quality of life.

Patients reporting poor physical quality of life complained of mostly of loss energy and fatigue, pain and discomfort, disrupted sleep and rest. Physiotherapy, yoga and exercise may increase their work capacity. Adequate treatment of pain and discomfort by medication needs to be ensured.

As having cancer is one of the most stressful conditions in one's life, so support groups of cancer survivors help them cope with the emotional aspect of cancer by organizing recreational activities and providing a safe place to share their feelings and challenge.

Patients' perception of environment domain of quality of life can be improved by providing suitable transport assistance as many of them (66.5\%) come from remote and rural areas to this tertiary care institute for treatment. Availability of Follow up services near their homes would also improve quality of life in this aspect. Thus a holistic approach involving primary care givers, psychologists, survivor groups as well as physicians may go a long way to improve the quality of life of cancer patients.

\section{References}

1. Cancer factsheet.cancerindia.org.in. Accessed on 28.12.17 at 2.00pm.

2. Nandakumar A. National Cancer Registry Program. India Council for Medical Research, Consolidated report of the 
population based cancer registries 1990-96. New Delhi: Indian Council of Medical Research;2009.

3. Dikshit R, Gupta PC, Ramasundarahettige C, et al. Cancer mortality in India: A nationally representative survey; 2012; Lancet;379 (9828):1807-16.

4. National Cancer Registry Program. Consolidated report of the population based cancer registries 1990-1996. New Delhi: Indian Council of Medical Research;2009.

5. World Cancer Report 2014. World Health Organization. 2014. pp. Chapter 1.1. ISBN 9283204298. Accessed from original on $27^{\text {th }}$ December 2017.

6. Boscolo-Rizzo P, Maronato F, Marchiori C, Gava A, Da Mosto MC. Longterm quality of life after total laryngectomy and postoperative radiotherapy versus concurrent chemoradiotherapy for laryngeal preservation. Laryngoscope 2008 Feb;118(2):300-306.

7. Webster K, Cella D. Quality of life in patients with lowgrade non-Hodgkin's lymphoma. Oncology 1998;12:697714.

8. Guyatt GH, Feeny DH, Patrick DL. Measuring healthrelated quality of life. Ann Intern Med 1993 Apr;118(8):622-629.

9. Wilson IB, Cleary PD. Linking clinical variables with health-related quality of life. A conceptual model of patient outcomes. JAMA 1995 Jan;273(1):59- 65.

10. Spilker B, ed. Quality of Life and Pharmacoeconomics in Clinical Trials. Philadelphia: Lippincott-Raven, 1996:11259.

11. Testa MA, Simonson DC. Assessment of quality-of-life outcomes. N Engl J Med 1996 Mar;334(13):835-840.

12. WHO (2003), Tech.Rep.Ser., N916

13. Bayumi H A, Mohamed HS. IOSR Journal of Nursing and Health Science (IOSR-JNHS) e-ISSN: 2320-1959.pISSN: 2320-1940 Volume 5, Issue 6 Ver. I (Nov. - Dec. 2016), PP 168-173. www.iosrjournals.org Accessed on 31.12 .17 at $4.00 \mathrm{pm}$.

14. Mansano-Schlosser TC, Ceolim MF. Quality of life of cancer patients during the chemotherapy period. Text Context Nursing, Florianópolis, 2012 Jul-Sep; 21(3):6007.

15. Michelone APC, Santos VLCG. Quality of life of cancer patients with and without an ostomy. Rev Latino-am Enfermagem 2004 Nov-Dec; 12(6):34-47.

16. Işıkhan V, Güner P, Kömürcü Ş, Özat A, Arpacı F, Öztürk B. The relationship between disease features and quality of life in patients with cancer-I. Cancer Nurs 2001;24:490-5.

17. Arslan S, Bölükbaşı N. Evaluation of the life quality of the patients with cancer. Atatürk Üniversitesi Hemşirelik Yüksekokulu Dergisi 2003;6:38-47.

18. Lee JH, Chen CH, Yao G, Chung CW, Sheu JC, Lee PH, et al. Quality of life in patients with hepatocellular carcinoma received surgical resection. J Surg Oncol. 2007 Jan;95(1):34-9.

19. Huguet PR, Morais SS, Osis MJD, Pinto-Neto AM, Gurgel MSL. Qualidade de vida e sexualidade de mulheres tratadas de 30ociod de mama. Rev Bras Ginecol Obstet. 2009;31(2):61-7.

20. Rabin EG, Heldt E, Hirakata VN, Fleck MP. Quality of life predictors in breast cancer women. Eur J Oncol Nurs 2008 Set;16(4):53-57.

21. Üstündag $\mathrm{S}$, Zencirci AD. Factors affecting the quality of life of cancer patients undergoing chemotherapy: A questionnaire study. Asia Pac J Oncol Nurs 2015;2:1725.

22. Lis CG, Cambron JA, Grutsch JF, Granick J, Grupda D. Self reported quality of life in users and nonusers of dietary supplements in cancer. Support Care Cancer 2006;14:193-9.

23. Yıldız, Özgüroğlu M, Toptaş T, Turna H, Sen F, Yı1dız M. Patterns of complementary and alternative medicine use among Turkish cancer patients. J Palliat Med 2013;16:383-90.

24. Knight SJ, Latini DM, Hart SL, Sadetsky N, Kane CJ, DuChane J, et al. Education predicts quality of life among men with prostate cancer cared for in the department of veterans affairs. Cancer 2007;109:1769-76.

25. Can G, Erol O, Aydıner A, Topuz E. Quality of life and complementary and alternative medicine use among cancer patients in Turkey. Eur J Oncol Nurs 2009; 13:287-94.

26. Güner P, Işı1khan V, Kömürcü S, Il S, Oztürk B, Arpaci F, et al. Quality of life and 30ociodemographic characteristics of patients with cancer in Turkey. Oncol Nurs Forum 2006; 33:1171-6.

27. Rogerson RJ. Environmental and health-related quality of life: conceptual and methodological similarities. Soc Sci Med. 1995 Jan;41:373-82.

28. Miller RC, Atherton PJ, Kabat FB, Fredericksen MB, Geno DM, Deschamps C, et al. Marital status and quality of life in patients with esophageal cancer or barrett's esophagus: The mayo clinic esophageal adenocarcinoma and barrett's esophagus registry study. Dig Dis Sci 2010; 55:2860-8

29. Armstrong T, Cohen MZ, Hess KR, Manning R, Lee EL, Tamayo G, et al. Complementary and alternative medicine use and quality of life in patients with primary brain tumors. J Pain Symptom Manage 2006;32:148-54. 